\title{
Medicine in Philately Hematology and Oncology with Stamps
}

\author{
Ahmet D. ATAMAN' ${ }^{1}$, E. Elif VATANOGLU-LUTZ ${ }^{2}$ \\ ${ }^{1}$ Vienna Medical Faculty, Department of History of Medicine, Vienna- AUSTRIA \\ ${ }^{2}$ Yeditepe University Medical Faculty, Department of Medical History and Ethics, Istanbul, TURKEY
}

\begin{abstract}
The importance given to blood and the understanding of cancer are the two oldest features of medical history. These two concepts are combined in our current description as hematologic oncology. Today the three main types of blood cancer are known as lymphoma, leukemia and multiple myeloma. Each varies slightly in terms of treatment, prognosis and symptoms. Beginning from the discovery of blood circulation and blood grouping, with many new techniques in diagnosis and treatment modalities; the approach to hematology and oncology evolved a lot. This paper provides an overview to the main historical aspects of hematology and leukemia through philately.
\end{abstract}

Keywords: Hematology, Leukemia, Pathology, History, Philately

ÖZET

Filatelide Tıp, Pullarla Hematoloji ve Onkoloji

Kana verilen önem ve kanserin tanınması tıp tarihinin en eski iki olgusudur. Bu iki kavram günümüzde hematolojik onkoloji tanımıyla biraraya getirilmiştir. Bugün bilinen üç kan kanseri türü lenfoma, lösemi ve multiple myeloma olarak sınıflandırılmaktadır. Her biri tedavi prognoz ve semptomlar açısından farkllıklar göstermektedir. Hematoloji ve onkoloijiye yaklaşımımız gerek kan dolaşımı ve kan gruplarının keşfi gerekse tanı ve tedaviye yönelik birçok yeni tekniğin gelişmesiyle birlikte köklü bir evrime uğramışır. Bu çaışma hematoloji ve löseminin temel tarihsel sürecine filateli aracılı̆ıı ile genel bir bakış sunmayı hedeflemektedir.

Anahtar Kelimeler: Hematoloji, Lösemi, Patoloji, Tarih, Filateli 


\section{INTRODUCTION}

Beginning from the prehistoric times, blood had been the most feared, revered, mythologized, and magical medical substance for human beings.We see that understanding blood was the center of medicine even in paleolithic period. ${ }^{1}$ Generally, Hippocrates is credited with being the first to recognize cancer in the 4 th or 5 th century B.C. (Figure 1). ${ }^{2,3}$

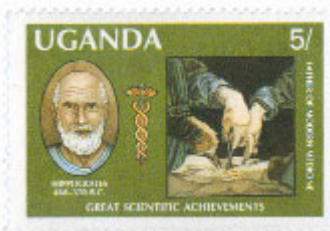

Figure 1. A stamp from Uganda issued in 1978 showing a portrait of Hippocrates and his pioneer role in the great scientific achievements of today

In 1932, Louis Leakey discovered a mandible in Kenya that looked like a malignant tumor and might have been Burkitt's lymphoma, a common cancer of the jaw in contemporary east Africa. The bones of a dinosaur that might have had cancer have been found from 150 million years ago (Figure 2). ${ }^{4}$

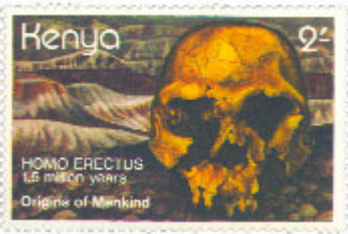

Figure 2. A stamp from Kenya issued in 1982 showing the anthropological research done in Kenya

Although cancer was less common before the twentieth century, humans have been getting cancer for a long time. Some explanations for the increase during the twentieth century are that more people are surviving who would have died of infectious disease and that in the past many times cancer may not have been properly diagnosed (Figure 3,4$)$. $^{5}$

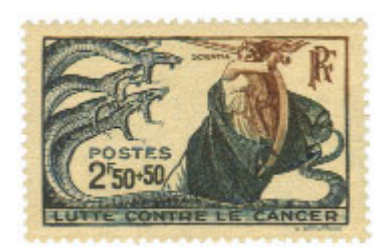

Figure 4. A stamp issued in Algeria in 1955 with the aim of getting public attention to cancer
Figure 3. A stamp issued in France in 1941 showing the endless struggle of humanity against cancer

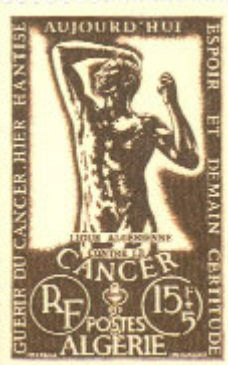

William Harvey's discovery of the circulatory system of the blood and Gaspae Aselli's explanation of the lymphatic system were very important for the diagnosis and understanding of cancer (Figure $5,6,7) \cdot 6,7$

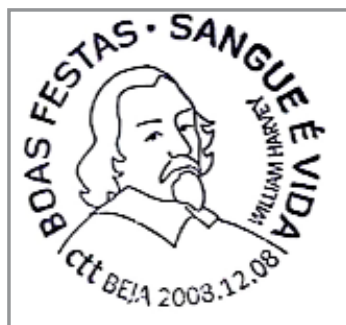

Figure 5. Special cancellation for William Harvey from 2008

Figure 6. Russian stamp from 1978 showing a portrait of William Harvey

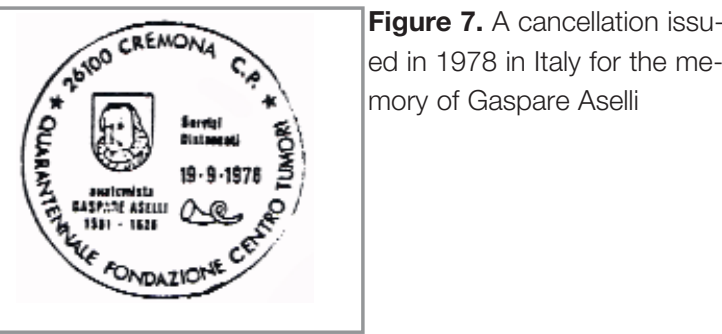

On the other hand, the discovery of blood grouping by Karl Landsteiner in 1901 paved the way for many other medical procedures that we don't even think twice about today, such as major surgery, blood banks, organ and stem cell transplants (Figure $8,9){ }^{8}$
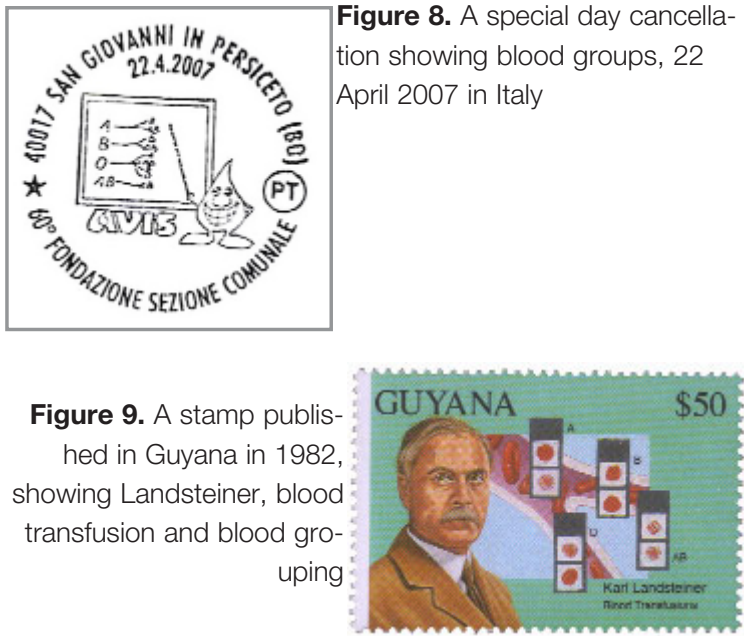


\section{The First Description of Leukemia}

Leukemia was not officially diagnosed until 1845 , when Rudolf Virchow described abnormally large number of white blood cells in a blood sample from a patient. ${ }^{9} \mathrm{He}$ was a very famous German physician and at the same time, he was one of the 19th century's foremost leaders in medicine and pathology. He was also a public health activist, social reformer, politician, and anthropologist. He is known as 'the father of modern pathology'. ' In 1845 he published a paper in which he described one of the two earliest reported cases of leukemia while he is studying pathological histology. He first used the term leukemia which he formed from the two Greek words leukos, meaning "white", and aima, meaning "blood" (Figure 10,11)..$^{10,11}$

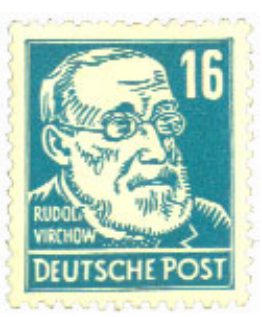

Figure 10. A German stamp of Rudolf Virchow, which was published in 1952

Figure 11. Rudolf Virchow is represented on a stamp from 27th October 1960, German Democratic Republic

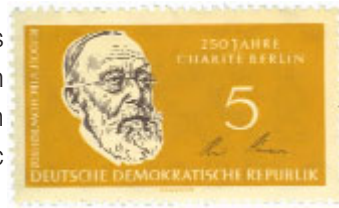

Today, leukemia is a common hematologic malignancy worldwide, with approximately 300,000 new cases (2.8\% of all cancer cases) and 220,000 deaths annually (Figure 12). ${ }^{12}$

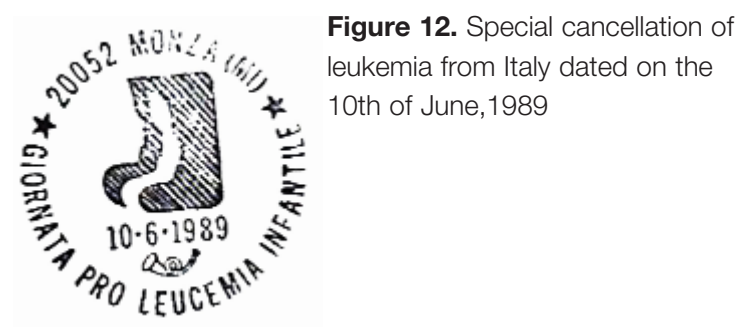

\section{Important Names after the First Description of Leukemia}

After the first description by Virchow, the journey of leukemia had so many milestones added by many scientists. He opened a major pathway in medicine by recognizing leukemia cells for the first time in history (Figure 13).

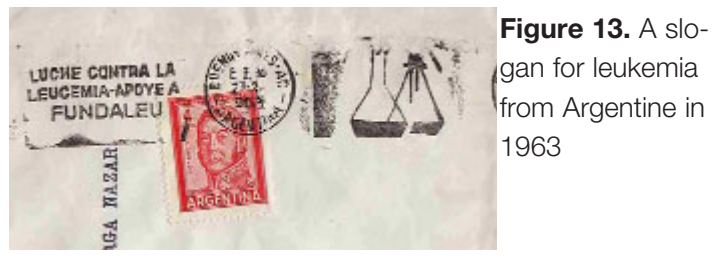

Around ten years after Virchow's findings, pathologist Franz Ernst Christian Neumann found that one deceased leukemia patient's bone marrow was colored "dirty green-yellow" as opposed to the normal red (Figure 14). ${ }^{13}$ This finding allowed Neumann to conclude that a bone marrow problem was responsible for the abnormal blood of leukemia patients. ${ }^{13}$

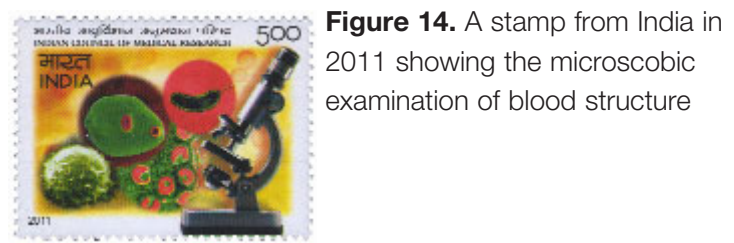

By 1900 leukemia was viewed as a family of diseases as opposed to a single disease. In 1947, a pathologist from Boston, Sidney Farber believed from past experiments that aminopterin, a folic acid mimic, could potentially cure leukemia in children. ${ }^{14}$ The majority of the children with acute lymphoblastic leukemia who were tested showed signs of improvement in their bone marrow, but none of them were actually cured. ${ }^{14}$ This, however, led to further experiments.

\section{Milestones in the Diagnosis and Treatment of Leukemia}

In the contemporary approach, diagnosis is usually based on repeated complete blood counts and a bone marrow examination following observations of the symptoms (Figure 15). ${ }^{12}$

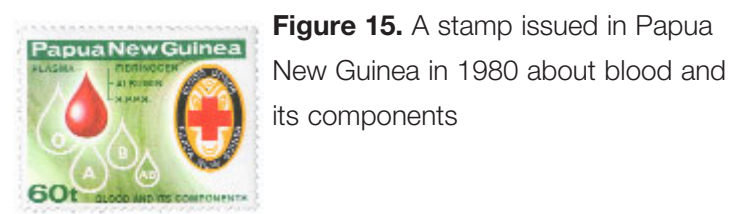

Historically, one of the most common treatments for leukemia was arsenic (Figure 16). ${ }^{15}$

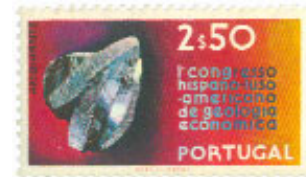

Figure 16. A stamp issued in Portugal in 1971 showing the chemical structure of arsenic 
This cure was used by Hippocrates (460-370 BC), who gave cancer its name, from the Greek term "carcinos" or "karkinos" and also recommended later by Albert Magnus in the $13^{\prime}$ th century (Figure $17,18) .^{2,15}$

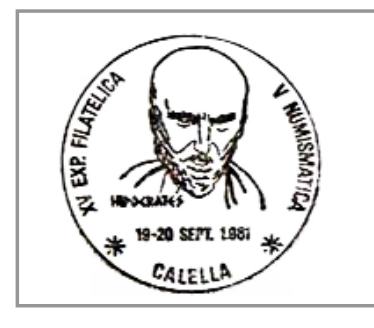

Figure 18. A stamp issued in Germany in 1980 for the memory of Albert Magnus

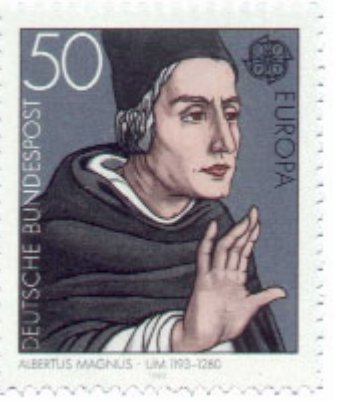

Arsenic became the primary therapy for leukemia, used up to the early 20th century, when it fell out of favor with the advent of radiation therapy. ${ }^{16,17}$ Around 1897, after the discovery of radiation, studies showed that $\mathrm{x}$-rays could reduce the size of tumors; it was discovered that daily doses of radiation over several weeks would greatly improve therapeutic response. 18After medical investigation, $\mathrm{x}$-ray radiation for patient therapy moved into the clinical routine in the early 1920s (Figure 19,20,21,22). ${ }^{18}$

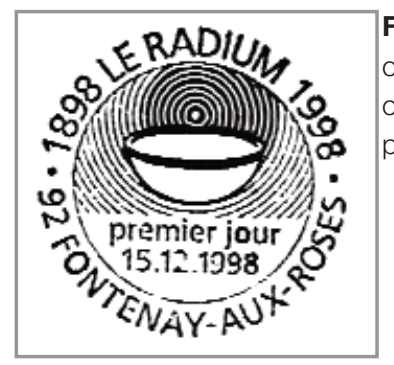

Figure 20. A stamp issued in Egypt in 1995 for the 100'th anniversary of the using $x$-rays in medicine
Figure 19. Special cancellation for the 100'th anniversary of the discovery of radium, published in France in 1998

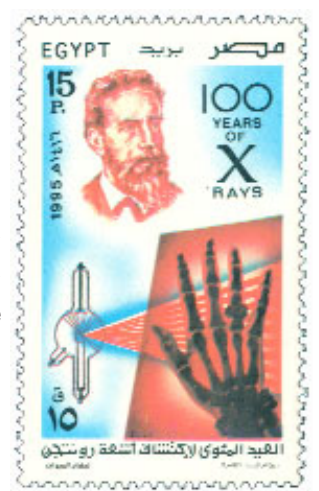

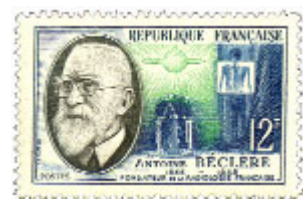

Figure 21. A stamp issued in France in 1957 for the memory of Antoine Beclere and emphasizing his contributions in the use of radiation

Figure 22. A stamp issued in Brazil in 1995 for the memory of Conrad Röntgen

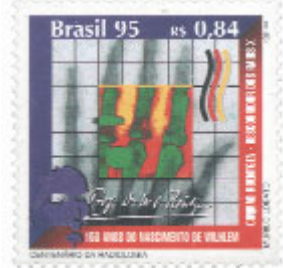

Shortly after becoming widely used, by the end of 1920s, Hermann Muller recognized that ionizing radiation could cause mutations in DNA that contributed to cancer (Figure 23,24). ${ }^{19}$

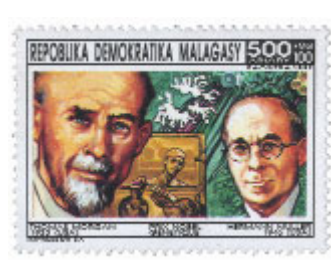

Figure 23. A stamp issued in Republic of Malagasy in 1992 showing Hermann Muller on the right end side.

Figure 24. A stamp issued in Maldives in 1995 showing a portrait of Hermann Muller

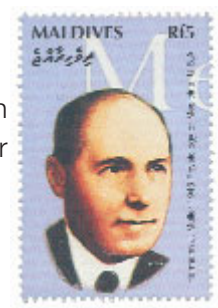

Until after World War II, there were no adequate treatments for leukemia. One of the most important treatments for cancer, chemotherapy, actually developed from an agent of chemical warfare used by the Germans during WWI, mustard gas, which attacks rapidly-dividing white blood cells (Figure $25) .^{20}$

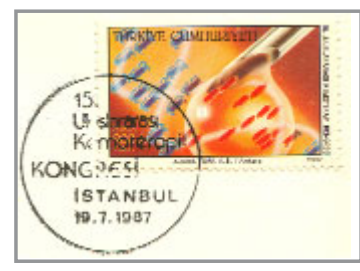

Figure 25. FDC (first day cover) from Turkey in 1987 for the 15th International Chemotherapy Congress in İstanbul

In the 1940s there were new treatments, such as aminopterin, first used by Sidney Farber of Boston to treat acute childhood leukemia. ${ }^{14}$

George Hitchings (1905-1998) and Gertrude Elion (1918-1999) used rational drug design to create 6- 
mercaptopurin, the first truly effective leukemia drug. ${ }^{21}$ Despite these new treatments, leukemia was not conquered. Many patients entered remission, but they later relapsed and died. Elion researched the drug intensively, with the result that today therapy uses 6-MP in combination with other drugs, and continues during remission (Figure 26). ${ }^{21}$

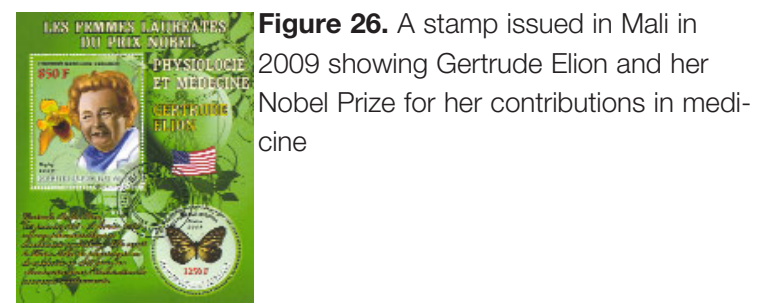

The greatest advances of the 20th century took place with the advent of the discovery of DNA by James Watson and Francis Crick. ${ }^{22}$ This led to a greater understanding of the detailed mechanisms of cancer, answering some questions and leading to a number of others (Figure 27,28).

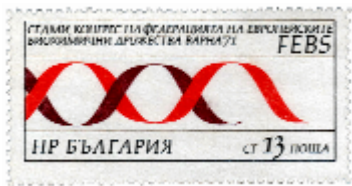

Figure 27. A stamp issued in 1971 in Bulgaria emphasizing their discovery of the structure of DNA

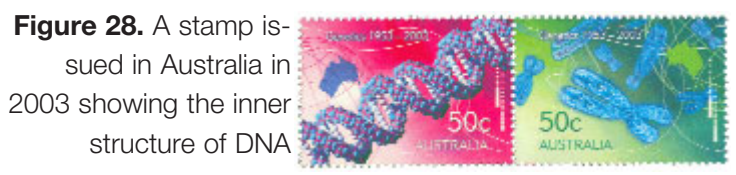

In addition to the environmental risk factors, as our understanding of DNA and genes increased, scientists learned that it was the damage to DNA by chemicals and radiation or introduction of new DNA sequences by viruses that often led to the development of cancer (Figure 29,30). ${ }^{23}$

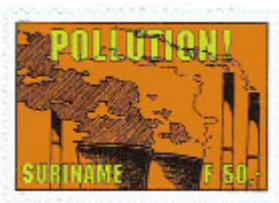

Figure 29. A stamp issued in Surinam in 1994 emphasizing the environmental pollution

Figure 30. A stamp issued in save our soll sAVE our cmies USA in 1970 showing the importance of environmental health for the universe and human beings

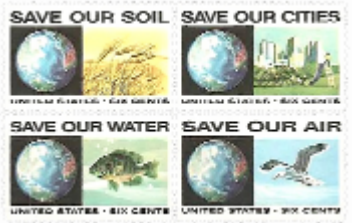

Also, hematopoietic stem cell transplantation has evolved over the last half century from experimental bone marrow transplantation for patients with incurable leukemia or bone marrow failure to standard of care for a broad range of patients with congenital or acquired disorders of the hematopoietic system or radio-, chemo- or immune-sensitive malignancies..$^{24}$ More than 60,000 such transplants are currently carried out annually worldwide with increasing frequency as transplantation in general is one of the most important life saving contemporary techniques (Figure $31,32,33$ ). ${ }^{24}$

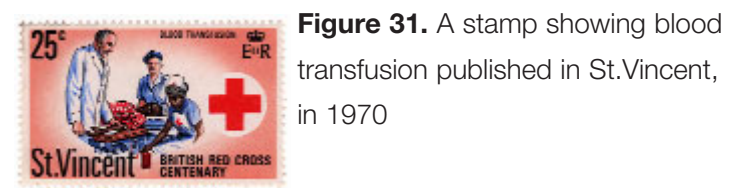

Figure 32. A stamp about blood donation, published in 1964 in Bulgaria
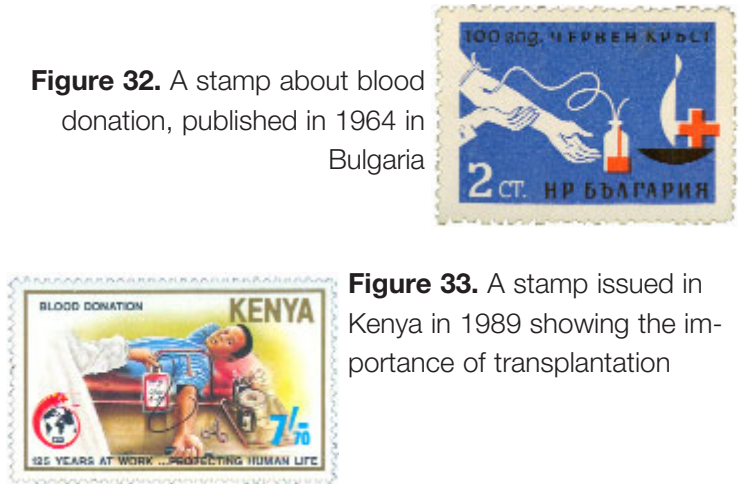

Figure 33. A stamp issued in Kenya in 1989 showing the importance of transplantation

In the future, genetic analysis may prove to uncover new treatments for diseases like leukemia. (Figure $34,35)$

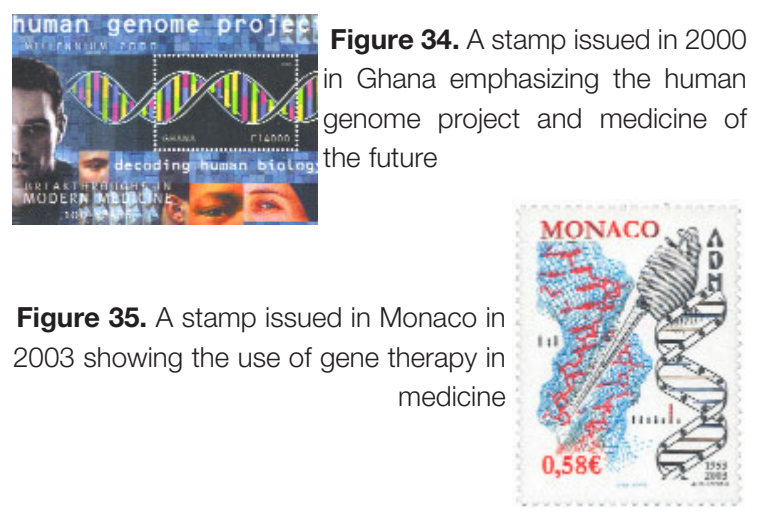

\section{CONCLUSION}

Besides the different types of leukemia as classified today, the increase of childhood leukemia in modern times may be lifestyle-related. In developed countries, families are usually smaller and hygiene has improved. Infants are no longer exposed to in- 
fections at an early age. Our immune systems have evolved to respond to infections shortly after birth, usually through the mother's antibodies during breast-feeding. ${ }^{25,26}$ The immune systems of children exposed at later ages, without having confronted microbes at an earlier age, may not respond as well. These children may have increased risk of developing leukemia. The incidence of leukemia is higher among more industrialized nations, and in those nations among people of higher socioeconomic status, because these people are living in an environment that is least like the environment humans evolved to fit. ${ }^{27}$ People in these privileged positions are exposed to more pesticides and chemicals, and fewer infectious diseases, than other people. ${ }^{28}$ Through the cultural perspective, it is seen that leukemias are often romanticized in the 20th century fiction. ${ }^{29}$ It is presented as a pure, clean disease, whose innocent, beautiful, and spiritually sensitive victims tragically die young. As such, it is the cultural successor to tuberculosis. ${ }^{29,30}$ Hopefully, in the near future, just like tuberculosis, all types of leukemias will be totally curable and eradicated.

\section{REFERENCES}

1. Zuskin E, Lipozenci J, Pucarin-Cvetkovi J, et al. Ancient medicine - A review. Acta Dermatovenerol Croat 16: 149-157, 2008.

2. Kanellou V. Ancient Greek medicine as the foundation of contemporary medicine. Tech Coloproctol 8: 3-4, 2004.

3. Karamanou M, Androutsos G, Diamantis A. Cancer and Roman medicine. J BUON 14: 537-540, 2009.

4. Day MH. Louis Leakey. J Anat 114: 463-464, 1973.

5. Parsa N. Environmental factors inducing human cancers. Iran J Public Health 41: 1-9, 2012.

6. de Micheli A, Izaguirre-Avila R. Evolution of knowledge on blood and its movement. 1st Part. Integration of circulatory doctrine, latrophysics of blood. Rev Invest Clin 56: 783-792, 2004.

7. Azzali G. Historical notes on the lymphatic vascular system. Acta Biomed Ateneo Parmense 61: 113-125, 1990.

8. Schwarz HP, Dorner F. Karl Landsteiner and his major contributions to haematology. $\mathrm{Br} J$ Haematol 121: 556-565, 2003.

9. Brown TM, Fee E. Rudolf Carl Virchow: Medical scientist, social reformer, role model. Am J Public Health 96: 2104-2105, 2006.
10. Kumar DR, Hanlin E, Glurich I, Mazza JJ, Yale SH. Virchow's contribution to the understanding of thrombosis and cellular biology. Clin Med Res 8: 168-172, 2010.

11. Bignold LP, Coghlan BL, Jersmann HP. Virchow's "cellular pathology" 150 years later. Semin Diagn Pathol 25: 140-146, 2008.

12. Patel MI, Ma Y, Mitchell BS, Rhoads KF. Understanding disparities in leukemia: a national study. Cancer Causes Control 23: 1831-1837, 2012.

13. Neumann-Redlin von Meding E. Neumann's dentin sheaths and Tomes' dentin fibers. On the 150th anniversary of the birth of Königsberg pathologist Ernst Christian Neumann. Dtsch Zahnarztl Z 39: 65-69, 1984.

14. Miller DR. A tribute to Sidney Farber- the father of modern chemotherapy. Br J Haematol 134: 20-26, 2006.

15. Collins DJ. Albertus, Magnus or Magus? Magic, Natural Philosophy, and Religious Reform in the Late Middle Ages. Renaissance Quarterly 63: 1-44, 2010.

16. Zhou J. Arsenic trioxide: an ancient drug revived. Chin Med J (Engl) 125: 3556-3560, 2012.

17. Doss M. Shifting the paradigm in radiation safety. Dose Response 10: 562-583, 2012.

18. Thariat J, Hannoun-Levi JM, Sun Myint A, Vuong T, Gérard JP. Past, present, and future of radiotherapy for the benefit of patients. Nat Rev Clin Oncol 10: 5260, 2012.

19. Calabrese EJ. Muller's Nobel lecture on dose-response for ionizing radiation: Ideology or science? Arch Toxicol 85: 1495-1498, 2011.

20. Ghanei M, Vosoghi AA. An epidemiologic study to screen for chronic myelocytic leukemia in war victims exposed to mustard gas. Environ Health Perspect 110: 519-521, 2002.

21. Kent R, Huber B. Gertrude Belle Elion (1918-99). Nature 398: 380, 1999.

22. Erdmann VA, Barciszewski J. 2011: 50th anniversary of the discovery of the genetic code. Angew Chem Int Ed Engl 50: 9546-9552, 2011.

23. Shah MV, Barochia A, Loughran TP Jr. Impact of genetic targets on cancer therapy in acute myelogenous leukemia. Adv Exp Med Biol 779: 405-437, 2013.

24. Gratwohl A, Niederwieser D. History of hematopoietic stem cell transplantation: evolution and perspectives. Curr Probl Dermatol 43: 81-90, 2012.

25. Hilton S. Breast milk breaks new boundaries. Pract Midwife 15: 37-39, 2012.

26. Belderbos ME, Houben ML, van Bleek GM, et al. Breastfeeding modulates neonatal innate immune responses: a prospective birth cohort study. Pediatr Allergy Immunol 23: 65-74, 2012.

27. Regulska K, Stanisz B, Regulski M. Individualization of anticancer therapy: Molecular targets of novel drugs in oncology. Postepy Hig Med Dosw 66: 855-867, 2012. 
28. Kittles R. Genes and environments: Moving toward personalized medicine in the context of health disparities. Ethn Dis 22: 43-46, 2012.

29. Morris DB. Illness and Culture in the Postmodern Age. University of California Press, Los Angeles, 2000: 240247.

30. Trowbridge B. The Hidden Meaning of Illness: Disease As a Symbol and Metaphor. A.R.E. Press, California, 1996: 78-89.

\section{Correspondence}

Dr. E. Elif Vatanoğlu-Lutz

Yeditepe Universitesi Tıp Fakültesi

Tıp Tarihi ve Etik Anabilim Dalı

İnönü Mahallesi, Kayışdağı Caddesi

26 Agustos Yerleşimi

34755 Kadiköy, ISTANBUL / TURKEY

Tel: (+90.216) 5780000 (ext 3078)

05436353171

e-mail: drvatanoglu@yahoo.com 